\title{
Antidiabetic effect of kolaviron, a biflavonoid complex isolated from Garcinia kola seeds, in Wistar rats
}

\author{
*Adaramoye $\mathrm{OA}$
}

Drug Metabolism and Toxicology Research Laboratories, Department of Biochemistry, Faculty of Basic Medical Sciences, University of Ibadan, Ibadan, Nigeria

\begin{abstract}
Background: Hypoglycaemic effect of kolaviron (KV), (biflavonoid from Garcinia kola) in streptozotocin (STZ)-diabetic rats has been established.

Objectives: To evaluate the possible protective effects of KV on cardiac, renal and hepatic tissues of STZ-diabetic rats.

Methods: This study consists of four groups of 6 rats each. Groups one and two contained non-diabetic and untreateddiabetic rats, respectively. Groups three and four were made up of $\mathrm{KV}$ - and glibenclamide (GB) - treated diabetic rats, respectively.

Results: STZ-intoxication caused a significant $(\mathrm{p}<0.05)$ increase in the relative weight of liver in diabetic rats. STZ-diabetic rats had significant increase $(\mathrm{p}<0.05)$ in the levels of fasting blood glucose $(\mathrm{FBG})$, á-amylase and $\mathrm{HbA}_{1 c}$. A marked and significant $(p<0.05)$ increase in the levels of cardiac, renal and liver marker indices such as serum creatine kinase, lactate dehydrogenase, creatinine, urea and alanine aminotransferase were observed in untreated diabetic rats. Also, untreated diabetic rats had significantly $(\mathrm{p}<0.05)$ elevated urinary glucose and protein and, lowered creatinine clearance. In KV-and GB- treated groups, the levels of FBG, á-amylase and $\mathrm{HbA}_{1 c}$ were significantly $(\mathrm{p}<0.05)$ reduced, while treatment with $\mathrm{KV}$ significantly $(\mathrm{p}<0.05)$ attenuated the cardiac, renal and liver marker indices.
\end{abstract}

Conclusion: $\mathrm{KV}$ offered significant antidiabetic and tissues protective effects in the rats.

Keywords: Antidiabetic, Kolaviron, Streptozotocin, Tissues, Protection

African Health Sciences 2012; (4): 498 - 506 http://dx.doi.org/10.4314/ahs.v12i4.16

\section{Introduction}

Diabetes mellitus is one of the most common chronic diseases and is characterized by absolute insulinopaenia or insufficient production of insulin or inadequate peripheral tissue response to physiological levels of insulin. Diabetic patients exhibit symptoms like hyperglycemia, polydipsia, polyuria and glucosuria. The number of adults (aged $\geq 20$ ) with diabetes in the world is estimated to increase by $122 \%$, from 135 million in 1995 to 300 million in $2025^{1}$. Chronic hyperglycemia leads to complications such as cardiovascular diseases, renal failure and retinopathy. Modern drugs, including insulin and other oral hypoglycaemic agents such as sulfonylureas and biguanides are known to control blood glucose levels but with side effects ${ }^{2}$. Besides,

\author{
*Corresponding author: \\ Dr. Oluwatosin A. Adaramoye \\ Department of Biochemistry \\ University of Ibadan \\ Nigeria \\ Tel.: +234808 8382846 \\ Email: aoadaramoye@yahoo.com
}

these drugs are expensive and not readily accessible in developing countries ${ }^{3}$. Hence, herbal remedy may be a potential alternative for the management of diabetes since they contain compounds with antioxidant activity that can play a role in protection against damage induced during diabetes ${ }^{4}$.

Garcinia kola Heckel (Family; Guttiferae) is a herb grown in Nigeria with a characteristic bitter and resinous taste. The seed is eaten raw by people with the belief that it promotes longevity. Extracts of the plant are used in traditional African medicine for the treatment of laryngitis, cough and liver diseases $^{5}$. Chemical investigations of the seed revealed the presence of Garcinia biflavanone (GB), xanthones, triterpenes and benzophenones ${ }^{6}$. Kolaviron (KV), a biflavonoid complex from the Garcinia kola seed is known to elicit hepatoprotective effect in animal model ${ }^{7,8}$. Several pharmacological effects of KV include anti-hypercholesterolemic activity $^{9}$, antioxidant activity ${ }^{10}$, and hypoglycemic effects in diabetic animals ${ }^{11}$. Accordingly, this study was designed to investigate the possible protective effects of KV on the cardiac, renal and hepatic tissues 
of STZ-diabetic rats, which are often prone to secondary complications of the disease.

\section{Methods}

\section{Chemicals}

Streptozotocin was purchased from Sigma Chemical Co., Saint Louis, MO USA. Serum biochemical analysis was done by automated system at Tehran University Teaching Hospital, Tehran, Iran. Other chemicals were of analytical grade and the purest quality available.

\section{Plant material and extraction}

Garcinia kola seeds (Guttiferae heckel) seeds were purchased from a local vendor in Ibadan, Nigeria. Kolaviron was extracted from the fresh seeds of the Kola $(3.5 \mathrm{~kg})$ and characterized according to the method of Iwu et al ${ }^{11}$, briefly, powdered seeds were extracted with light petroleum ether (b.p. $40-60^{\circ} \mathrm{C}$ ) in a soxhlet extractor for $24 \mathrm{hr}$. The defatted, dried marc was repacked and then extracted with methanol. The extract was concentrated and diluted to twice its volume with distilled water and extracted with ethyl acetate (6.250 litres). The concentrated ethyl acetate fraction gave a yellow solid known as kolaviron (figure 1). The purity and identity of kolaviron was determined by subjecting it to thinlayer chromatography (TLC) using Silica gel GF 254coated plates and, solvent mixture of methanol and chloroform in a ratio 1:4 v/v. The separation revealed the presence of three bands which were viewed under UV light at a wavelength of $254 \mathrm{~nm}$ with RF values of $0.48,0.71$ and $0.76^{6}$. The yield of the preparation was $6 \%$.

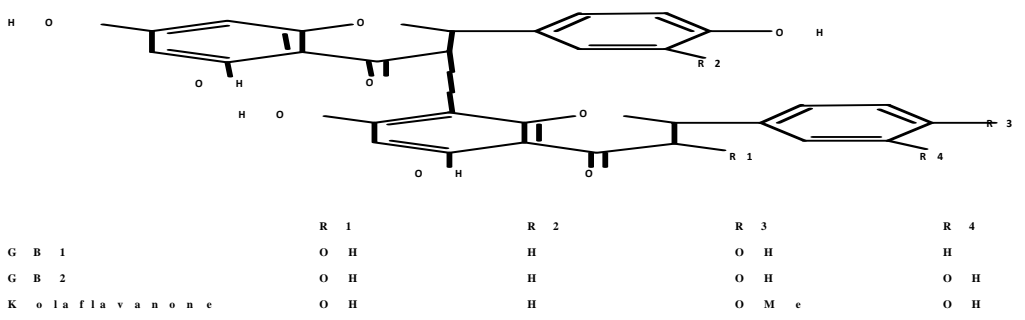

Figure 1: Structure of Kolaviron

\section{Animals}

Male Wistar rats, 220-230 g, were used for the study. The rats were 10-12 weeks of age at the time of this study. They were bred and housed in the Central Animal House, Faculty of Pharmacy, Tehran University of Medical Sciences, University of Tehran, Iran. The animal house was well ventilated with a 12-h light-dark cycle. They were fed on normal laboratory chow and allowed free access to water for two weeks before the commencement and during the period of the experiment. Handling of animals and other protocols conform to the guidelines of the National Institutes of Health (NIH), USA (NIH publication $85-23,1985)^{12}$.

\section{Study design}

The effect of kolaviron (KV) administered daily for 3 consecutive weeks was studied in STZ-diabetic rats. The procedure described by Sharma et al. ${ }^{13}$ was adopted in this study. Rats were fasted overnight and made hyperglycemic by a single intraperitoneal injection of STZ dissolved in $0.05 \mathrm{M}$ of citrate buffer ( $\mathrm{pH} 4.3$ ), at a dose of $35 \mathrm{mg} / \mathrm{kg}^{14}$. The FBG of these rats were estimated $72 \mathrm{~h}$ after STZ administration, and moderately diabetic rats having FBG level above $250 \mathrm{mg} / \mathrm{dL}$ were selected and divided into three groups of 6 animals each. Group one contained nondiabetic rats (Normal), group two consisted of untreated STZ-diabetic rats, group three contained STZ-diabetic rats that received KV and group four contained glibenclamide (GB)-treated STZ-diabetic rats. KV and GB were dissolved in corn oil and normal saline, respectively, and given daily to the animals by oral gavage. KV was administered at a dose of $100 \mathrm{mg} / \mathrm{kg}$ body weight ${ }^{12}$ and, GB at a dose of $5 \mathrm{mg} / \mathrm{kg}^{15}$. After the last dose of the drugs, rats were fasted overnight and sacrificed by cervical dislocation. Visceral organs were obtained by dissection and immediately weighed, while blood was collected from the heart of the animals into plain centrifuge tubes. Also, 24-h urine free of food and faeces was collected into ice-cold glass tubes for the determination of protein, glucose and creatinine. 


\section{Preparation of Serum}

Blood samples were allowed to stand for 1 hour and then centrifuged at 3,000 $\mathrm{g}$ for 15 minutes in an MSC bench centrifuge to obtain serum. The clear supernatant (serum) was used for the estimation of urea, creatinine, enzymes and other parameters.

\section{Biochemical assays}

Protein determination: Protein contents of serum and urine were determined according to Lowry et $\mathrm{a}^{16}$ using bovine serum albumin (BSA) as a standard.

Alanine and Aspartate aminotransferases (ALT and AST) determination: Serum ALT and AST activities were determined by the combined methods of Mohun and Cook $^{17}$ and, Reitman and Frankel ${ }^{18}$.

Creatine kinase, creatinine and urea determination: Creatinine and urea levels were estimated by the methods of $\mathrm{Jaffe}^{19}$ and, Talke and Schubert ${ }^{20}$, respectively, while creatine kinase was measured in the presence of an antibody to CK-M monomer utilizing a kit purchased from United Diagnostics Industry (Riyadh, SA).

Determination of glucose and total bilirubin levels: Glucose and total bilirubin levels were determined by the methods of Sharma et $\mathrm{al}^{13}$ and, Rutkowski and Debaare $^{21}$, respectively.

Determination of ã-glutamyl transferase (GGT) activity: The activity of serum GGT was assayed by the method of Fossati et $\mathrm{al}^{22}$.

Alpha amylase and lactate debydrogenase (LDH) determination: The activities of á-amylase and $\mathrm{LDH}$ were determined by the methods of Gella et $\mathrm{al}^{23}$ and, Zimmerman and Weinstein ${ }^{24}$, respectively.

Determination of alkaline phosphatase (ALP) and $\mathrm{Hb} A_{1 c}$ levels: $\mathrm{HbA}_{1 \mathrm{c}}$ and ALP levels were determined by the methods of Hirokawa et $\mathrm{al}^{25}$ and Williamson ${ }^{26}$, respectively.

\section{Statistical analysis}

All values were expressed as the mean \pm S.D. of six animals per group. Data were analyzed using oneway ANOVA followed by the post-hoc Duncan multiple range test for analysis of biochemical data using SPSS (10.0). Values were considered statistically significant at $\mathrm{p}<0.05$.

\section{Results}

Effect of KV on body weight, á-amylase, $\mathrm{HbA}_{1 \mathrm{c}}$ and FBG of STZ-diabetic rats

Table 1 shows the effect of KV on body weight and relative weight of organs of STZ-diabetic rats. The final body weight of STZ-diabetic rats decreased significantly $(\mathrm{p}<0.05)$ when compared with normal. Treatment with $\mathrm{KV}$ and $\mathrm{GB}$ significantly $(p<0.05)$ increased the final body weight of the diabetic rats. Also, the decrease in body weight was highest for untreated STZ-diabetic rats when compared with GB- and KV- diabetic rats. In addition, the STZ-induced increase in relative weight of liver was significantly $(\mathrm{p}<0.05)$ attenuated in $\mathrm{KV}$ and GB- treated diabetic rats. At the end of this study, the FBG levels of STZ-diabetic animals treated with KV and GB decreased significantly $(\mathrm{p}<0.05)$ when compared with untreated diabetic group (figure 2). STZ-intoxication caused a significant $(\mathrm{p}<0.05)$ increase in the levels of a -amylase and $\mathrm{HbA}_{1 \mathrm{c}}$ of the rats (table 2 and figure 5), however, treatment with both KV and GB significantly $(\mathrm{p}<0.05)$ decreased the $\mathrm{HbA}_{1 \mathrm{c}}$ levels of the diabetic rats, while $\mathrm{KV}$ alone caused significantly $(\mathrm{p}<0.05)$ decrease in the activities of á-amylase when compared to untreated diabetic group. Thus, KV was more effective than GB in lowering the $\mathrm{HbA}_{1 \mathrm{c}}$ levels as well as attenuating the activities of á-amylase in the diabetic rats.

Table 1: Effect of kolaviron, a biflavonoid fraction from Garcinia kola seeds, on body weight and relative weight of organs in STZ-diabetic rats

\begin{tabular}{|c|c|c|c|c|c|c|c|c|c|}
\hline \multirow[t]{2}{*}{ Treatment } & \multicolumn{3}{|c|}{ Body weight (g) } & \multicolumn{3}{|c|}{ Weight (g) } & \multicolumn{3}{|c|}{$\begin{array}{l}\text { Relative weight } \\
\text { (as \% body weight) }\end{array}$} \\
\hline & Initial & Final & Change & Liver & Kidney & Heart & Liver & Kidney & Heart \\
\hline Normal & $225.1 \pm 5.3$ & $241.3 \pm 6.2$ & $16.2 \pm 5.6$ & $6.8 \pm 0.5$ & $1.3 \pm 0.1$ & $0.8 \pm 0.1$ & $2.8 \pm 0.3$ & $0.5 \pm 0.09$ & $0.3 \pm 0.05$ \\
\hline TZ only & $226.3 \pm 4.7$ & $178.0 \pm 9.1 *$ & $-48.3 \pm 8.3^{*}$ & $7.1 \pm 0.8$ & $1.2 \pm 0.2$ & $0.8 \pm 0.1$ & $4.0 \pm 0.3^{*}$ & $0.6 \pm 0.07$ & $0.4 \pm 0.05$ \\
\hline STZ+KV & $223.4 \pm 5.5$ & $215.2 \pm 4.1^{* *}$ & $-8.2 \pm 2.4 * *$ & $6.9 \pm 0.4$ & $1.3 \pm 0.2$ & $0.8 \pm 0.2$ & $3.2 \pm 0.2^{* *}$ & $* 0.6 \pm 0.10$ & $0.4 \pm 0.03$ \\
\hline $\mathrm{STZ}+\mathrm{GB}$ & $228.4 \pm 4.4$ & $204.6 \pm 8.0 * *$ & $-23.8 \pm 7.3^{*}$ & $7.2 \pm 0.8$ & $1.3 \pm 0.2$ & $0.8 \pm 0.1$ & $3.5 \pm 0.4^{* x}$ & $* 0.6 \pm 0.08$ & $0.4 \pm 0.08$ \\
\hline
\end{tabular}

Values are means \pm S.D. of 6 rats per group

** Significantly different from STZ only at $\mathrm{p}<0.05$

$\mathrm{GB}=$ Glibenclamide
* Significantly different from normal at $\mathrm{p}<0.05$

$\mathrm{STZ}=$ Streptozotocin, $\mathrm{KV}=$ Kolaviron at $100 \mathrm{mg} / \mathrm{kg}$ 


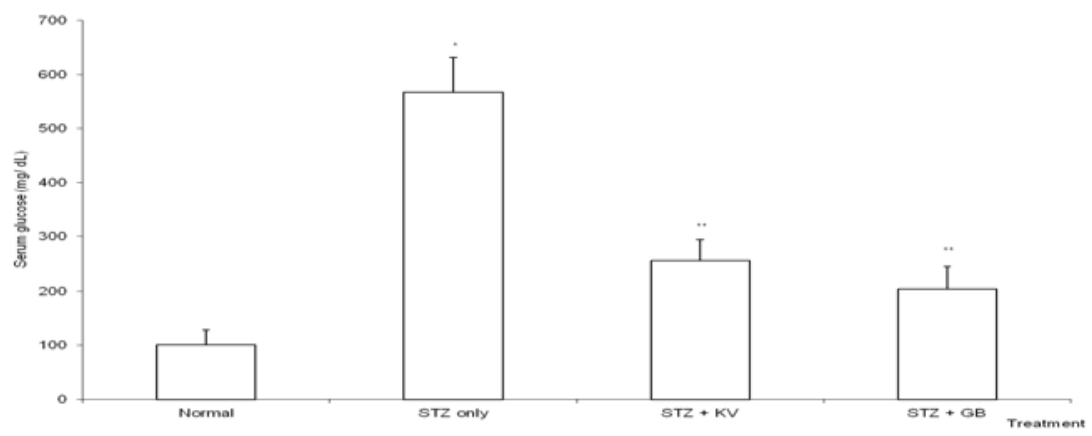

Figure 2: Effect of kolaviron (biflavonoid of Garcinia kola) on the levels of fasting glucose of streptozotocin (STZ)-diabetic rats

*Significantly different from normal $(\mathrm{p}<0.05),{ }^{* *}$ Significantly different from normal and STZ only $(\mathrm{p}<0.05)$, $\mathrm{KV}=$ Kolaviron at $100 \mathrm{mg} / \mathrm{kg}, \mathrm{GB}=$ Glibenclamide

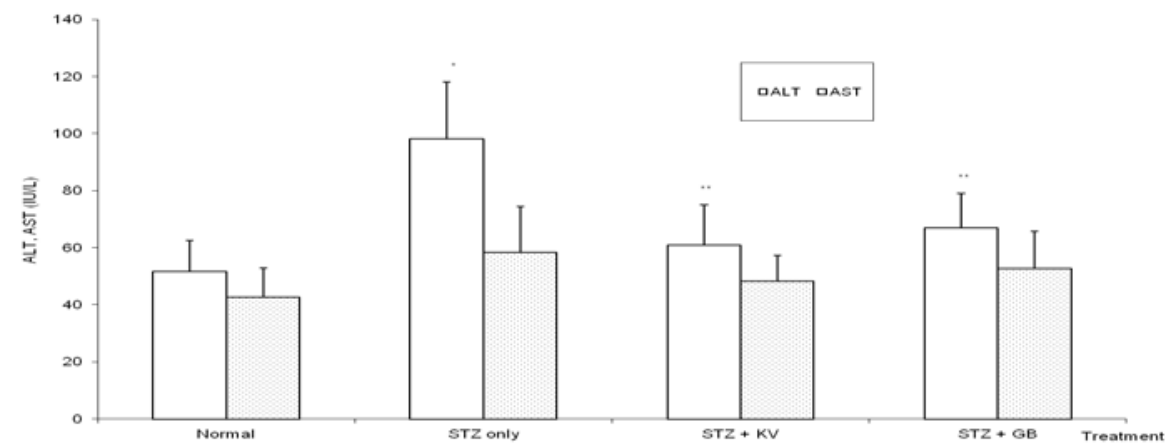

Figure 3: Effect of kolaviron (biflavonoid of Garcinia kola) on the activities of alanine and aspartate aminotransferases in streptozotocin (STZ)-diabetic rats

*Significantly different from normal $(\mathrm{p}<0.05)$, **Significantly different from STZ only $(\mathrm{p}<0.05)$, $\mathrm{KV}=$ Kolaviron at $100 \mathrm{mg} / \mathrm{kg}, \mathrm{GB}=$ Glibenclamide, ALT $=$ Alanine aminotransferase, AST $=$ Aspartate aminotransferase

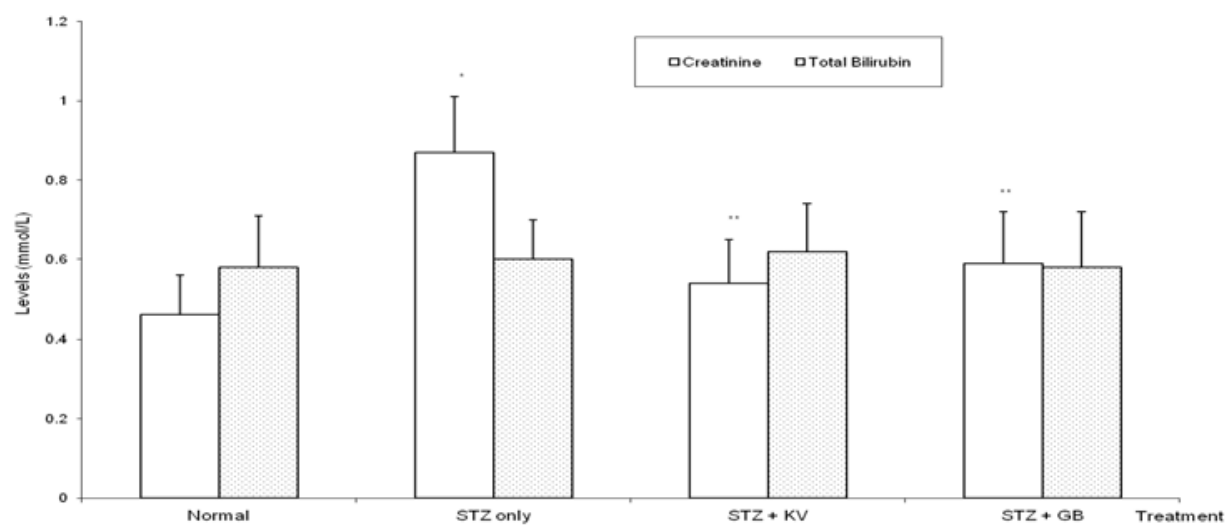

Figure 4: Effect of kolaviron (biflavonoid of Garcinia kola) on the levels of serum creatinine and total bilirubin activities in streptozotocin (STZ)-diabetic rats

*Significantly different from normal $(\mathrm{p}<0.05), * *$ Significantly different from STZ only $(\mathrm{p}<0.05)$, $\mathrm{KV}=$ Kolaviron at $100 \mathrm{mg} / \mathrm{kg}, \mathrm{GB}=$ Glibenclamide 


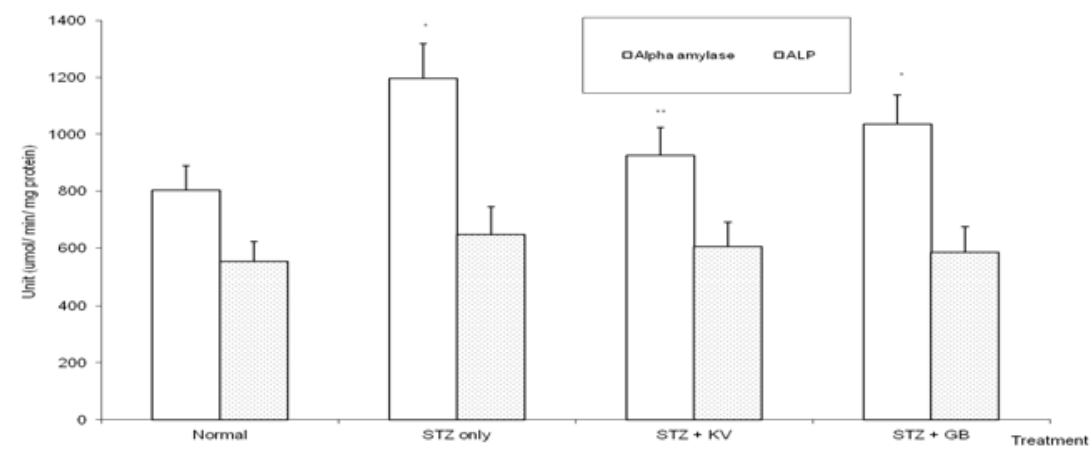

Figure 5: Effect of kolaviron (biflavonoid from Garcinia kola) on the activities of serum alkaline phosphatase and á-amylase in streptozotocin (STZ)-diabetic rats

*Significantly different from normal $(\mathrm{p}<0.05)$, **Significantly different from STZ only $(\mathrm{p}<0.05)$, $\mathrm{KV}=$ Kolaviron at $100 \mathrm{mg} / \mathrm{kg}, \mathrm{GB}=$ Glibenclamide, $\mathrm{ALP}=$ Alkaline phosphatase

Effect of KV on urinary and serum markers of kidney functions in STZ diabetic rats

STZ-intoxication caused a significant increase $(\mathrm{p}<$ $0.05)$ in urinary glucose and protein of the rats when compared with normal (table 2). Precisely, the levels of urinary glucose and protein were increased by $291 \%$ and $386 \%$, respectively, in untreated diabetic rats. Furthermore, urinary creatinine levels (a measure of creatinine clearance) decreased significantly $(\mathrm{p}<0.05)$ in untreated diabetic rats. However, administration of KV and GB significantly $(\mathrm{p}<0.05)$ reversed the adverse effects of STZ on urinary biochemical indices of the animals. In untreated STZdiabetic rats, serum urea and creatinine levels significantly $(\mathrm{p}<0.05)$ increased when compared to normal (figures 4 and 6 ), while both $\mathrm{KV}$ - and GBtreated diabetic rats had significantly $(\mathrm{p}<0.05)$ lowered serum creatinine levels when compared to untreated diabetic group. KV alone was able to reverse the STZ-induced increase in urea levels to values that were statistically similar $(\mathrm{p}>0.05)$ to normal (figure 6).

Table 2: Effect of kolaviron, a biflavonoid fraction from Garcinia kola seeds, on urinary and blood biochemical indices in STZ-diabetic rats

\begin{tabular}{|c|c|c|c|c|c|c|}
\hline \multirow[t]{3}{*}{ Treatment } & \multirow{2}{*}{\multicolumn{2}{|c|}{ Serum }} & \multirow{2}{*}{\multicolumn{3}{|c|}{ Urine }} & \multirow{3}{*}{$\begin{array}{l}\text { Red cell } \\
\mathrm{HbA}_{1 \mathrm{c}} \\
(\%)\end{array}$} \\
\hline & & & & & & \\
\hline & $\begin{array}{l}\text { Protein } \\
(\mathrm{mg} / \mathrm{dL})\end{array}$ & $\begin{array}{l}\mathrm{LDH} \\
(\mathrm{IU} / \mathrm{L})\end{array}$ & $\begin{array}{r}\text { Glucose } \\
(\mathrm{mg} /\end{array}$ & $\begin{array}{ll}\text { Protein } & \text { C } \\
24 \mathrm{~h}) & (\mathrm{r} \\
\end{array}$ & $\begin{array}{l}\text { Creatinine } \\
(\mathrm{ml} / \mathrm{min} / 100 \mathrm{~g})\end{array}$ & \\
\hline Normal & $1.82 \pm 0.46$ & $501.8 \pm 31.2$ & $2.2 \pm 0.4$ & $0.7 \pm 0.06$ & $0.62 \pm 0.09$ & $4.2 \pm 0.3$ \\
\hline STZ only & $1.63 \pm 0.38$ & $1007 \pm 51.3^{*}$ & $8.6 \pm 1.3 *$ & $3.4 \pm 0.5^{*}$ & $0.15 \pm 0.04 *$ & $8.3 \pm 0.4^{*}$ \\
\hline $\mathrm{STZ}+\mathrm{KV}$ & $1.89 \pm 0.50$ & $613.2 \pm 41.0^{* *}$ & $3.2 \pm 0.7 * *$ & $1.3 \pm 0.07 * *$ & $0.43 \pm 0.07 * *$ & $5.0 \pm 0.4^{* *}$ \\
\hline$\underline{\mathrm{STZ}}+\mathrm{GB}$ & $1.86 \pm 0.44$ & $998.5 \pm 39.2 *$ & $2.7 \pm 0.5^{* *}$ & $1.1 \pm 0.05^{* *}$ & $* * 0.37 \pm 0.05 * *$ & $6.2 \pm 0.2 * *$ \\
\hline
\end{tabular}

Values are means \pm S.D. of 6 rats per group $\quad *$ Significantly different from normal at $\mathrm{p}<0.05$

** Significantly different from STZ only at $\mathrm{p}<0.05 \mathrm{STZ}=$ Streptozotocin, KV= Kolaviron at $100 \mathrm{mg} / \mathrm{kg}$, $\mathrm{GB}=$ Glibenclamide, HbA1c $=$ Glycosylated hemoglobin, $\mathrm{LDH}=$ Lactate dehydrogenase

Effect of KV on cardiac and liver function indices in STZ-diabetic rats

Table 2 and figure 7 show that STZ intoxication caused significant $(\mathrm{p}<0.05)$ increase in the activities of serum creatine kinase $(\mathrm{CK})$ and lactate dehydrogenase $(\mathrm{LDH})$ (Cardiac marker enzymes). Treatment with KV alone significantly $(\mathrm{p}<0.05)$ ameliorated the adverse effect of STZ on the activities of CK and LDH. Furthermore, the activities of serum alanine aminotransferase (ALT) and gamma glutamyl transferase (GGT) were significantly $(p<0.05)$ elevated in untreated diabetic rats relative to normal (figures 3 and 6). Specifically, the activities of ALT and GGT were increased by $90 \%$ and $67 \%$, respectively. However, treatment with either KV or GB significantly $(\mathrm{p}<0.05)$ reduced the levels of serum ALT and GGT of the diabetic rats. In contrast, STZ administration produced insignificant ( $p>0.05)$ effect on the levels of serum total bilirubin and alkaline phosphatase in the animals. 


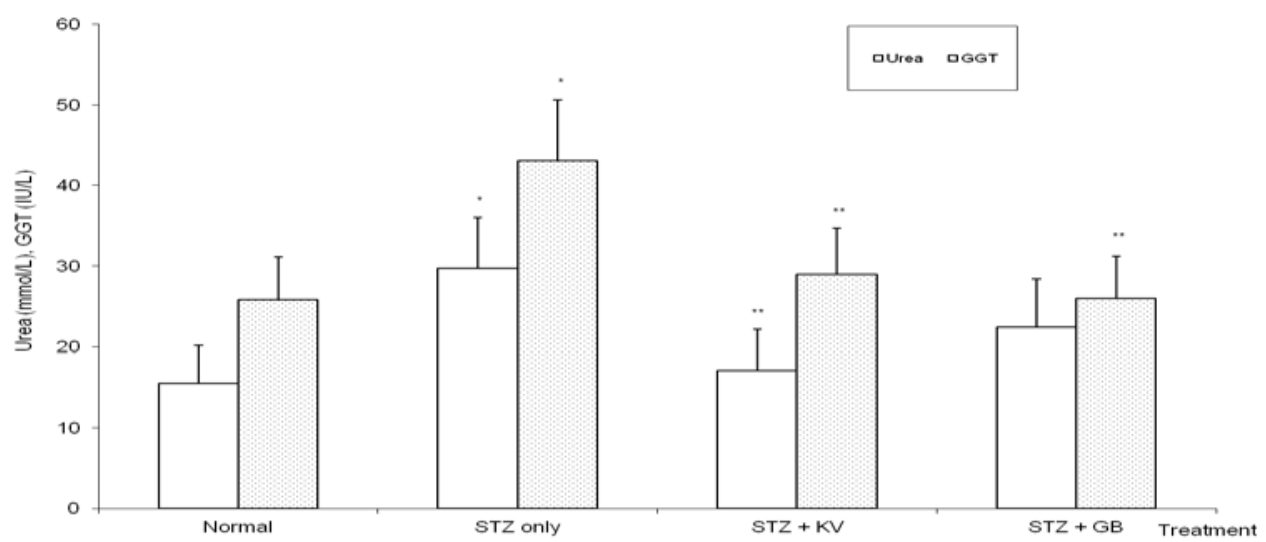

Figure 6: Effect of kolaviron (biflavonoid from Garcinia kola) on the levels of serum gamma glutamyl transferase and urea in streptozotocin (STZ)-diabetic rats

*Significantly different from normal $(\mathrm{p}<0.05), * *$ Significantly different from STZ only $(\mathrm{p}<0.05)$, $\mathrm{KV}=$ Kolaviron at $100 \mathrm{mg} / \mathrm{kg}, \mathrm{GB}=$ Glibenclamide, GGT= Gamma glutamyl transferase

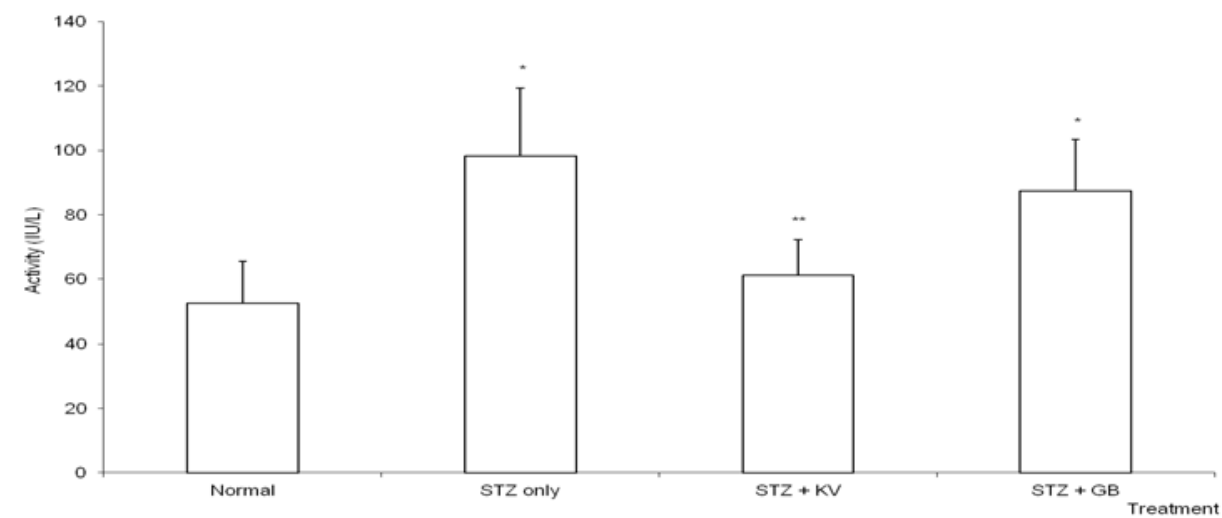

Figure 7: Effect of kolaviron (biflavonoid from Garcinia kola) on the activities of serum creatine kinase in streptozotocin (STZ)-diabetic rats

*Significantly different from normal $(\mathrm{p}<0.05), * *$ Significantly different from STZ only $(\mathrm{p}<0.05)$, $\mathrm{KV}=$ Kolaviron at $100 \mathrm{mg} / \mathrm{kg}, \mathrm{GB}=$ Glibenclamide

\section{Discussion}

Diabetes mellitus is one of the most common chronic diseases and is associated with hyperglycaemia and comorbidities such as obesity and hypertension. The use of a lower dose of STZ ( $35 \mathrm{mg} / \mathrm{kg}$ ) was to produce a partial destruction of â-cells, while the rats also become permanently diabetic $^{27}$. Since the â-cells are not completely destroyed the rats do not require insulin to survive ${ }^{28}$. In diabetes, hyperglycaemia is a common feature and can inactivate existing enzymes by glycating their protein, leading to DNA cleavage ${ }^{29}$. The increased level of blood glucose in STZ -diabetic rats was lowered by both KV and GB. Reports are available regarding the antidiabetic and antihyperlipidemic activities of $\mathrm{KV}$ at $100 \mathrm{mg} / \mathrm{kg}^{11}$, which were confirmed in this study. Glycosylated haemoglobin $\left(\mathrm{HbA}_{1 \mathrm{c}}\right)$ expresses the percentage of haemoglobin bound to glucose. This sensitive index measures the mean blood glucose level over a period of 6-8 weeks (life span of red blood cells) and it reflects glycemic control in patients ${ }^{30}$. In this study, the levels of $\mathrm{HbA}_{1 \mathrm{c}}$ significantly increased in untreated diabetic rats. This observation is consistent with the findings of Fuji and Nomoto $^{31}$ that reported a significant change in the $\mathrm{HbA}_{1 \mathrm{c}}$ level after two weeks of STZ administration in rats. Treatment with KV significantly reduced the $\mathrm{HbA}_{1 \mathrm{c}}$ level relative to untreated diabetic rats, and better than in GB-treated diabetic rats. This result points to the ability of $\mathrm{KV}$ to regulate the blood glucose level in the rats better than GB for the 3 
weeks duration of this study. It is known that for every $1 \%$ drop in $\mathrm{HbA}_{1 \mathrm{c}}$ value may lead to $35 \%$ reduction in the risk of microvascular complications, including myocardial infarction in type 2 diabetes $^{32}$.

The cardiotoxicity of xenobiotics can be evaluated using the serum activity of marker enzymes especially LDH and creatine kinase (CK), which are distributed throughout the body and have isoenzymes that are recognized as markers for liver muscle and heart lesion ${ }^{33}$. Contradictory reports are available in the literature on the relationship between diabetes and CK activity ${ }^{34,35}$. However, Hayden and Tyagi ${ }^{28}$ linked the observed increase in the serum CK and LDH levels of diabetic rats to cardiac muscular damage caused by the disease. Also, Wiernsperger ${ }^{29}$ stated that the quantity of CK and $\mathrm{LDH}$ released is a measure of the state of necrosis in these tissues during diabetes.

In line with the findings of Hayden and Tyagi $^{28}$, the serum CK and LDH activities of untreated STZ-diabetic rats which were significantly elevated in this study indicates damage to cardiac muscle of the rats. It was observed that treatment of diabetic rats with $\mathrm{KV}$ at $100 \mathrm{mg} / \mathrm{kg}$ significantly attenuated $\mathrm{CK}$ and $\mathrm{LDH}$ activities during the 3 weeks of the study. This observation is very remarkable and points to the cardioprotective effect of this biflavonoid in the diabetic animals. In addition, liver enzymes such as ALT, AST, ALP, and GGT reflect different functions of the liver, such as hepatocellular integration, formation, and subsequent free flow of bile and protein synthesis. ALT and AST are important indicators of hepatocellular damage ${ }^{36}$. In the present study, ALT activities increased by 2 -folds in untreated diabetic rats relative to normal. Also, there was a significant increase in the GGT levels in untreated diabetic rats. GGT is found in hepatocytes and biliary epithelial cells and, can leak to blood in pancreatic disease, renal failure, and diabetes ${ }^{36}$. Oral administration of $\mathrm{KV}$ and $\mathrm{GB}$ to diabetic rats caused a significant decrease in the activities of both ALT and GGT. This means that $\mathrm{KV}$ has some hepatoprotective potentials in diabetic rats by decreasing serum ALT and GGT levels.

In this study, STZ-intoxication caused a significant elevation of urinary glucose and protein, and drastic fall in creatinine clearance. The increase in urinary protein and glucosuria in these animals indicates proximal tubular dysfunction. Furthermore, renal dysfunction in these rats was confirmed by the elevation of serum urea. Elevated levels of blood urea and creatinine have been documented in experimental and human diabetes ${ }^{37}$. Our data 504 indicate that $\mathrm{KV}$ at a dose of $100 \mathrm{mg} / \mathrm{kg}$ reduced the levels of serum urea, urinary glucose and protein and, improved creatinine clearance in STZ-diabetic rats. These results show the protective effects of $\mathrm{KV}$ against diabetic-induced renal dysfunction in these animals. Previous studies have attributed the biological effects of $\mathrm{KV}$ to its strong antioxidant property ${ }^{10,38}$ which cannot be ruled out in the present study.

\section{Conclusion}

This study confirmed that cardiac, renal and hepatic function indices were significantly elevated during STZ-induced diabetes, and that oral administration of $\mathrm{KV}$ reduced the levels of some of the indices. Therefore, KV may offer protection for tissues of animals during diabetes. Further studies are required to define a novel pathway by which KV affects diabetes using pancreatic â-cell line.

\section{Acknowledgements}

This study was supported by 3 months visiting fellowship (Ref. 3240207975) from TWASUNESCO Associateship programme given to OA to work in the laboratory of Professor Ali MoosaviMovahedi, Institute of Biochemistry and Biophysics, University of Tehran, Iran. The supports from Research Council of the University of Tehran, Tehran University of Medical Science and Iran National Science Foundation (INSF) are gratefully acknowledged.

\section{References}

1. King H, Aubert RE, Herman WH. Global burden of diabetes, 1995-2025: prevalence, numerical estimates, and projections. Diabetes Care 1998; 21: 1414-1431.

2. Nissen SE, Wolski K. Effects of rosiglitazone on the risk of myocardial infarction and death from cardiovascular cause. NEnglJ Med 2007; 356: 2457-2471.

3. Adeneye AA, Agbaje EO. Pharmacological evaluation of oral hypoglycaemic and antidiabetic effects of fresh leaves ethanol extract of Morinda lucida Benth. in normal and alloxan-induced diabetic rats. Afr J Biomed Res 2008; 11: 65-71.

4. Vaya J, Belinky PA, Aviram M. Antioxidant constituents from licorice roots: isolation, structure elucidation and antioxidative capacity

African Health Sciences Vol 12 Issue 4 December 2012 
toward LDL oxidation. Free Radic Biol Med 1997; 23: 302-13.

5. Iwu MM, Igboko OA. Flavonoids of Garcinia kola seeds. J. Nat Prod. 1982; 45: 650651.

6. Cotterhill PJ, Scheinmann F, Stenhouse TA. Extractives from Guttiferae: kolaflavanone, a new biflavanone from the nuts of Garcinia kola Heckel. J Chem Soc Perkin Trans 1978; 1: 246.

7. Iwu MM, Igboko OA, Onwuchekwa U, Okunji CO. Evaluation of the antihepatotoxicity of the biflavonoids of Garcinia kola seeds. J Ethnopharmacol 1987; 21: 127-38.

8. Adaramoye OA, Adeyemi EO. Hepatoprotection of D-galactosamineinduced toxicity in mice by purified fractions from Garcinia kola seed. Basic Clin Pharmacol Toxicol 2006a; 98: 135-141.

9. Adaramoye OA, Nwaneri VO, Anyanwu KC, Farombi EO, Emerole GO. Possible antiatherogenic effect of kolaviron (A Garcinia kola seed extract) in hypercholesterolemic rats. Clin Exp Pharmacol Physiol 2005a; 32: 40-46.

10. Adaramoye OA, Farombi EO, Adeyemi EO, Emerole GO. Inhibition of human lowdensity lipoprotein oxidation by flavonoids of Garcinia kola seeds. Pak J Med Sci 2005b; 21: 331-339.

11. Iwu MM, Igboko OA, Okunji CO, Tempesta MS. Anti-diabetic and aldose reductase activities of biflavanones of Garcinia kola. J Pharm Pharmacol 1990; 42: 290-292.

12. National Institutes of Health (US). Guide for the Care and Use of Laboratory Animals. NIH Publication No. 85-23. Revised 1985.

13. Sharma SR, Dwivedi SK, Swarup D. Hypoglycemic, antihyperglycemic and hypolipidemic activities of Caesalpinia bonducella seeds in rats. J Ethnopharmacol 1997; 58: 39 44.

14. Nakhoda A, Wong HA. The induction of diabetes in rats by intramuscular administration of streptozotocin. Experientia 1979; 35: 1679 1680.

15. Farswan M, Mazumder PM, Percha V. Protective effect of Cassia glauca Linn. on the serum glucose and hepatic enzymes level in streptozotocin induced NIDDM in rats. Indian J Pharmacol 2009; 41: 19-22.

African Health Sciences Vol 12 Issue 4 December 2012
16. Lowry OH, Rosebrough NJ, Farr AL, Randall RJ. Protein measurement with the Folin phenol reagent. J Biol Chem 1951; 193: 265-275.

17. Mohun AF, Cook LJ. Simple method for measuring serum level of glutamateoxaloacetate and glutamate-pyruvate transaminases in laboratories. J Clin Pathol 1957; 10: 394-399.

18. Reitman S, Frankel S. A colorimetric method for the determination of serum level of glutamate-oxaloacetate and pyruvate transaminases. Am J Clin Pathol 1957; 28: $56-$ 63.

19. Jaffe M. Ueber den Neiderschlag, welchen Pikrinsäure im normalen harn Erzeught und über eine neue Reaction des Kreatinins. $Z$ Physiol Chem 1886; 10: 391-400.

20. Talke H, Schubert GE. Enzymatische Harnstoff bestimmung in Blut and serum in Optischen Test nach Warburg. Klin Wochschr 1965; 43:174.

21. Rutkowski RB, Debaare L. An ultra-micro colorimetric method for determination of total and direct serum bilirubin. Clin Chem 1966; 12: 432-438.

22. Fossati R, Melzid'Eril GV, Turenghi G, Precipe L, Berti G. A kinetic colorimetric assay of gamma-glutamyltransferase. Clin Chem 1986; 32: 1581-1584.

23. Gella FJ, Gubern G, Vidal R, Canalias F. Determination of total and pancreatic alphaamylase in human serum with 2-chloro-4nitrophenyl-alpha-D-maltotrioside as substrate. Clin Chim Acta 1997; 259: 147-160.

24. Zimmerman HJ, Weinstein BS. Lactic dehydrogenase activity in human serum. J Lab \& Clin Med 1956; 48: 607-609.

25. Hirokawa K, Shimoji K, Kajiyama N. An enzymatic method for the determination of hemoglobin $A_{1 C}$. Biotechnol Lett 2005; 27: 963 968.

26. Williamson T. A comparison between the phosphastrate and phenyl phosphate methods of alkaline phosphatase assay. Med Lab Technol 1972; 29: 182-187.

27. Aybar MJ, Sánchez Riera AN, Grau A, Sánchez SS. Hypoglycemic effects of water extract of Smallanthus soncifolius (yacan) leaves in normal and diabetic rats. $J$ Ethanopharmacol 2001; 74: 125-132.

28. Hayden MR, Tyagi SC. Intimal redox stress: accelerated atherosclerosis in metabolic 
syndrome and type 2 diabetes mellitus. Atheroscleropathy Cardiovasc Diabetol 2002; 1:38.

29. Wiernsperger NF. Oxidative stress as a therapeutic target in diabetes: revisiting the controversy. Diabetes Metab 2003; 29: 579-585.

30. Ghacha R, Sinha AK, Karkar AM. HbA1c and serum fructosamine as marker of chronic glycemic state in type 2 diabetic hemodialysis patients. Dialysis Transplant 2001; 30: 214-217.

31. Fuji E, Nomoto T. Changes in glycosylated hemoglobin in short and semi long term streptozotocin-diabetic mice and rats. Japan J Pharmacol 1984; 34: 113-115.

32. UKPDS group. Intensive blood glucose control with sulphonylurea or insulin compared with conventional treatment and risk of complications in patients with type 2 diabetes. Lancet 1998; 352: 837-853.

33. Aldrich JE. Clinical enzymology. In: Anderson SC, Cockayne S, eds. Clinical Chemistry: Concept and Applications. New York: McGraw Hill, 2003: 261-284.
34. Zhao X, Bassirat M, Zeinab K, Helme RD. Effects of diabetes on creatine kinase activity in streptozotocin-diabetic rats. Chin Med J (Engl) 1999; 112: 1028-1031.

35. Al-Shabanah AO, El-Kashef HA, Badary OA, Al-Bekairi AM, Elmazar MM. Effect of streptozotocin-induced hyperglycemia on intravenous pharmacokinetics and acute cardiotoxicity of doxorubicin in rats. Pharmacol Res 2000; 41: 31-37.

36. Limidi JK, Hyde GM. Evaluation of abnormal liver function tests. Postgrad Med J 2003; 79: 307-312.

37. Yousef WM, Omar AH, Ghanayem NM. Effect of some calcium channel blockers in experimentally induced diabetic nephropathy in rats. Int J Diabetes Metab 2006; 14: 39-49.

38. Farombi EO, Shrotriya S, Surh YJ. Kolaviron inhibits dimethyl nitrosamine-induced liver injury by suppressing COX-2 and iNOS expression via NF-kappaB and AP-1. Life Sci 2009; 84: 149-155. 